\title{
Geopolitics or Geobody Politics? Understanding the Rise of China and Its Actions in the South China Sea
}

\author{
Hiroaki Ataka
}

\begin{abstract}
The "rise of China," especially within U.S. academic and policy circles, has been increasingly analyzed through a geopolitical lens. Yet geopolitics alone cannot account for the complex political mobilization of historical memory and how it frames any discussion of peace and cooperation in the region. Drawing on the concept of geobody, or how space and people are connected in a biopolitical manner, this article examines how the territorial disputes in the South China Sea are remaking the identity and interests of China. It develops an alternative theoretical understanding of China's rise that focuses on identity (or geobody) politics, and explores the risks involved in a further escalation of tensions for peace and cooperation in the area, and in East Asia more generally.
\end{abstract}

Keywords maritime disputes, South China Sea, China’s "peaceful rise," identity politics, geobody politics

\section{Introduction}

There is no gene for invasion in Chinese people's blood, and Chinese people will not follow the logic that "might is right." ... China will firmly stick to the path of peaceful development. (Xi Jinping 2014) ${ }^{1}$

China has reclaimed over 2,000 acres, more than all other claimants combined, and more than in the entire history of the region.... The United States is deeply concerned about the pace and scope of land reclamation in the South China Sea, the prospect of further militarisation, as well as the potential for these activities to increase the risk of miscalculation or conflict among claimant states. (Ashton Carter 2015) ${ }^{2}$

An increasingly popular and dominant approach on "the rise of China," especially within U.S. academic and policy circles, is to focus on geopolitics

(C) 2016 The Institute for Peace and Unification Studies, Seoul National University ISSN 2288-2693 Print, ISSN 2288-2707 Online 
(Kaplan 2014; Mead 2014). Typically underpinned by a (neo-)Realist logic that rising and status quo powers will inevitably clash, a common theme emerging from such analyses is that increasingly strong and rising China is seizing the moment to forcefully change the status quo. While differences over the prospect of peace and cooperation do remain, even Liberals, who have traditionally denounced such an idea, now seem to be adopting the idea that some kind of transhistorical logic will inevitably lead the United States (as the status quo power) and China (as the rising power) to collide (Liff and Ikenberry 2014). Viewed through a geopolitical lens, therefore, Chinese actions in the South China Sea are interpreted as an opportunistic projection of raw power; notions such as "peaceful rise" or "peaceful development" are merely calculative gestures to buy time for further military buildup in the region and beyond, ultimately challenging the influence and outreach of the current hegemon. Yet if both governments are playing the same strategic game, as suggested by the proponents of geopolitics, questions remain as to why Washington and Beijing are sending out such seemingly contradicting messages over the South China Sea, as seen from the quotes above? And what are the risks involved in a further escalation of tensions for peace and cooperation in the region, and in East Asia more generally?

In order to answer these questions, this article argues that a renewed look at the identity formation of the Chinese state is necessary to fully understand the contrasting signals between the two sides. The limits of geopolitical analysis, and the (neo-)Realist theory that underpins it, are that it assumes a solid, fixed identity and interest to exist prior to interaction. And with identities and interests being equal among all states, it boils down to the distribution of power or capabilities (and their calculation) to decide the next action for states. So it logically flows from this line of thinking that both the United States and the People's Republic of China are (and should be) calculating in a similar strategic fashion, focusing on the changes in relative power, and with the United States expecting the ambitions of rising China to expand as their material capabilities increase. Indeed, it is seen as natural that Beijing strives to further exert its influence in the surrounding region, including the South China Sea. Washington, therefore, is signaling that a forceful change of the status quo is not worthwhile by strengthening the ties with regional allies in Southeast Asia, thereby ultimately trying to alter China's strategic calculations. In this sense, geopolitical analyses are not merely descriptive (what is) but also prescriptive (how it should be) (Kirshner 2012).

Yet the descriptions/prescriptions that these approaches offer do not provide a dynamic view of a state's identity and interests, leading to fears that the policy implications arising from such analyses may not be telling the whole story; they can even result in heightened risk of miscalculation or conflict. What if China doesn't "act like a realist" and doesn't focus solely on the (material) balance of power? What if things like domestic politics, nationalism or historical memory 
do play an integral part in determining the next move, rather than ultimately being an irrelevant set of factors that Realists dismiss in understanding Beijing's intentions? Indeed, recently Chinese reactions to the maritime territorial disputes in the South China Sea seem to have significantly intensified, as the land reclamation projects and the rhetoric surrounding them suggest. It can thus be problematic to merely assume a strategic game being played on the (South)East Asian chessboard, since the players might be presupposing a different logic to the game being played, or even a different game altogether (Nye 2011).

By contrast, this article argues that an alternative approach to identity formation of the Chinese state is necessary, one that examines how political practices such as securing borders can in turn constitute the state's identity. Critical Security and Border Studies imply that borders are (and should be seen as) constitutive of political life-as historically contingent, politically charged, and dynamic phenomena. Drawing on the concept of geobody, or how space and people are connected in a biopolitical manner, this article suggests how the territorial disputes and its associated practices in the South China Sea are remaking the identity, and consequently interests, of China. It points out that intensified territorial disputes may lead to further geobody politics in China and throughout the region, distorting the genuine strategic game of pursuit of political and economic interests as suggested by the geopolitical view, thereby increasing the possibilities for miscalculation or conflict. This article therefore attempts to develop an alternative theoretical understanding of the rise of China and its implications for territorial disputes in the South China Sea, one that focuses on identity (or geobody) politics, which supplements the dominant geopolitical analysis.

The article is structured as follows. First, the geopolitical view on the rise of China and its actions in the South China Sea is outlined, while looking at some of the limits of such analysis. It will be suggested that a fresh look at the identity formation of the Chinese state is necessary to fully understand its position on the maritime disputes in the region. Second, an alternative approach to understanding China's rise is introduced, focusing on its identity political aspects. Drawing on the recent "practice turn" in Critical Security Studies and insights from Critical Border Studies, it will be pointed out that the act of maintaining its borders is in itself constitutive of the state and its identity. The notion of "geobody politics" is then introduced to highlight how the intensified territorial disputes and their associated practices are instead forming the identity of the Chinese state. Having outlined both the geopolitical and geobody political view of the rise of China, the third section explores theoretically the risks involved in a further escalation of tensions. The conclusion follows on to outline what the alternative theoretical understanding tells us about the prospects for peace and cooperation in the region and in East Asia more generally. 


\section{"Peaceful Rise" of China? Geopolitical View and its Limits}

The implications of the rapid rise of China over the last 30 years, and whether it will inevitably lead to a clash with the dominant great powers, particularly the United States, has been a recurring theme within both academic and policy circles. Within the contours of such debates, one area that has attracted heated discussion concerns the question of China's new assertiveness (Johnston 2013; Chen, Pu, and Johnston 2013). According to Alastair Iain Johnston, assertiveness refers to "a form of assertive diplomacy that explicitly threatens to impose costs on another actor that are clearly higher than before" (Johnston 2013, 10). It has been argued that the 2008 global financial crisis was a turning point in the shifting balance of power from the West to the East, particularly to China (Christensen 2015). The increased influence of BRICS, with its own summit and development bank, as well as the much discussed establishment of the Asian Infrastructure Investment Bank, are just a few examples of this shift to the East.

Yet the most typical manifestation of China's assertive policy is its actions in the South China Sea (Yahuda 2013). These waters have long been a flashpoint, demonstrated by China's seizure of the Paracel Islands from Vietnam in 1974 and again, in 1988, when they clashed over the Spratly Islands. Yet renewed Chinese efforts since 2012 to exert its influence over most of the South China Sea have triggered concerns and responses from neighboring countries and the wider world (Tri and Collin 2014). Despite the fact that Vietnam, the Philippines, Malaysia, Taiwan and Brunei all have overlapping maritime territorial claims, it has been the Chinese claim covering almost all of the South China Sea-the so-called nine-dash line-that has been the most contentious. ${ }^{3}$ After the SinoPhilippine maritime standoff in the Scarborough Shoal, in April 2012, Beijing stepped up efforts to consolidate its territorial claims by formally creating Sansha City (located on Woody Island or Yongxing Dao, one of the disputed formations in the Paracels) to administratively oversee its territory in the region. The Chinese government has sought to reinforce such maritime claims by representing most of the South China Sea as an integral part of its sovereign territory on its official map, by moving the center of the map further south and depicting itself as a maritime power (Tharoor 2014). The most recent case of such Chinese provocations came in the form of intensified land reclamation activities in the disputed Paracel and Spratly island chains, catching worldwide media attention in April 2015. It has been feared that the consolidation of such Chinese territorial claims may lead to the "Finlandization" of Southeast Asia (Kaplan 2014), while some even argue for "a kind of suzerainty" in the (re)making (Majid 2014, 401).

These recent developments in the South China Sea have given renewed impetus to the U.S. debates on the rise of China. Unsurprisingly, the most vocal assessments have come from the Realists who focus on geopolitics, arguing that the rise of a new great power (China) will inevitably lead to a clash with the old 
guard (the United States). For instance, Graham Allison (2012; 2015) poses the question: "Can China and the US escape Thucydides's trap?"4 Drawing on the classical narrative of the Peloponnesian War, Allison examines the dangers that the two parties face when a rising power rivals a ruling power-as in classical Greece with Athens challenging Sparta, or the early twentieth century when Germany challenged Great Britain. Analyzing historical cases, the project found that over the past 500 years, 12 out of 16 cases of rivalry resulted in war. Allison thus concludes that "based on the current trajectory, war between the United States and China in the decades ahead is not just possible, but much more likely than recognized at the moment. Indeed, judging by the historical record, war is more likely than not" (Allison 2015). In a similar vein, albeit more theoretically driven, John Mearsheimer (2014, ch. 10) asks: "Can China rise peacefully?” Drawing on offensive realism, Mearsheimer (375-376) argues that if China continues to grow, it will strive to become a regional hegemon in Asia since overpowering your potential rivals is the only way to ensure survival, and also because it offers the best pathway for China to resolve its (remaining) difficult territorial disputes on favorable terms. Since the United States will go to great lengths to prevent China from achieving regional hegemony, and with neighboring countries joining the containment strategy, Mearsheimer concludes that a rise of China will inevitably result in intense security competition and, potentially, war. ${ }^{5}$ Furthermore, Robert D. Blackwill and Ashley J. Tellis (2015) claim that China is trying to "replace" the United States as the primary power in Asia, and the United States therefore needs to balance against China as a rising power.

A common theme running through these observations is that they treat the rise and fall of the great powers as a kind of transhistorical reality: the rapid rise of China will inevitably lead to increased tensions between the old and new hegemons. ${ }^{6}$ Here, Chinese actions in the South China Sea seemingly support the argument that Beijing is pushing for economic interests and/or security maximization in the region, and that China "knows what it's doing." From such views, Chinese actions are interpreted as an opportunistic projection of raw power; the self-image as a peacefully rising power is merely a calculated gesture to buy time for furthering its "true" intention of a military buildup in (South)East Asia.

Sinologists have questioned such analysis, however, arguing that domestic Chinese debates on "grand strategy" or "core interests" remain vague at best. For instance, Feng Zhang $(2012,339)$ historically traces whether China has developed a coherent grand strategy (i.e., conjunction of national interests and strategic ideas) in the reform era (1978-present), and concludes that "today's China is unclear about its international purpose and unable to clarify what it stands for.... Vagueness about its values and interests does not help to reassure the world of China's rise." Similarly, Yaqing Qin (2014) notes that while the "assertive China" 
discourse has become widespread, it is too simplistic to merely assume that China has abandoned its "keeping-a-low-profile" strategy altogether and has adopted a "striving-for-achievement" stance. ${ }^{7}$ Rather than assuming a tectonic shift in grand strategy, Qin points out that "continuity through change" is a more realistic assessment of Chinese foreign policy, with emphasis on its cultural heritage of zhongyong or "taking the middle course." Jinghan Zeng, Yuefan Xiao, and Shaun Breslin $(2015,266)$ summarize the domestic debate on China's "core interests," concluding that while there is a consensus of sorts that China is misunderstood, and that powerful forces are looking to paint China in a negative light, there is no consensus on what exactly the core interests are for China.

Furthermore, it has also been suggested that the Chinese state should not be seen as unitary but as fragmented, decentralized and internationalized; it could thus be misleading to assume that there is (or must be) a rational and unified Chinese response to international affairs, as assumed by the proponents of geopolitics outlined above. Nowhere is this more evident than in the South China Sea, where various national and subnational government agencies have operated without coordination amongst themselves. The Ministry of Foreign Affairs "clearly does not control China's SCS [South China Sea] policy" (Hameiri and Jones 2016, 87). An International Crisis Group report sketches how the Bureau of Fisheries Administration of the Agriculture Ministry, China Marine Surveillance, provincial governments, the People's Liberation Army Navy, the national oil companies and six law enforcement agencies under four different ministries are each pursing their own institutional interests, increasing tensions in the region (International Crisis Group 2012, 8-13). This partially explains some of the provocative Chinese actions in the disputed waters, such as China National Offshore Oil Corporation's decision to develop energy reserves in the disputed waters near the Paracels in May 2011.

It could therefore be concluded that the very idea of a Chinese "grand strategy" to which the geopolitical analysis points is problematic, since it projects a view of foreign policy that assumes that a fixed and clearly defined identity and interest of a state informs its decisions and behavior. A renewed look at the identity formation of the Chinese state is therefore necessary to fully understand its actions and intent in the South China Sea.

\section{Geobody Politics: An Alternative View on the Rise of China}

Rather than speculating on how China will act based on its "core interests" in the South China Sea, or how it will rationally react to the geopolitical environment informed by its grand strategy rooted in a solid state identity, a more fruitful approach is to examine the process by which such identity is formed and how the politics of such identity formation drives the maritime disputes in Southeast Asia. 
This analysis will therefore reverse the equation by looking at how the political practice of securing borders and claiming sovereign territories itself constitutes China's identity and consequently its interests.

A useful starting point to see how political practices make possible strategic interactions (and more generally international relations) is the so-called practice turn in IR. ${ }^{8}$ According to Emanuel Adler and Vincent Pouliot $(2011,6)$ :

Practices are competent performances. More precisely, practices are socially meaningful patterns of action which, in being performed more or less competently, simultaneously embody, act out, and possibly reify background knowledge and discourse in and on the material world. Practices, such as marking a linear territorial boundary, deterring with nuclear weapons, or finance trading, are not merely descriptive "arrows" that connect structure to agency and back, but rather the dynamic material and ideational processes that enable structures to be stable or to evolve, and agents to reproduce or transform structures.

As patterned actions that are embedded in a particular context and repeated over time and space, practice as a focus enables a shift away from the rationalist models of action that rely on abstract calculation of interests, towards an understanding of how it's "actually done" on the ground (Bueger and Gadinger 2015).

Adler and Pouliot (2011,7-8) outline five aspects of practice. First, practice is a performance; that is, a process of doing something. Practices are different from preferences or beliefs, which are expressed, and from discourse or institutions, which they instantiate. Second, practice is patterned; it exhibits certain regularities over time and space. Practices are repeated. Third, practice must be competent in a socially meaningful way. Practices are expected to be (though not always) interpreted using similar standards. Fourth, practice rests on background knowledge, which it embodies, enacts, and reifies all at once. In other words, involved parties need to share an understanding of "how it's done." Fifth, practice connects the discursive and the material worlds. Therefore, contrary to the Realists who consider practice solely as material representation of interests, a focus on political practice enables a bottom-up approach to international relations, uncovering how it constitutes different dimensions of world politics (Pouliot and Cornut 2015).

Such focus on political practice has seen growing salience in the field of Critical Security Studies, particularly with regard to border politics. ${ }^{9}$ Traditional theories of international relations take sovereignty, territory and border as concepts that emerged historically, but are nonetheless natural. Sovereign states and the modern state system are seen as fundamental characteristics of "the international," where borders are treated as simple lines that distinguish the sovereign territory of states, dividing the domestic and the international 
in an unambiguous manner. By contrast, critical approaches view borders as constitutive of political life, meaning that the mere practice of maintaining and managing borders itself produces the inherent logics of inside/outside, practices of inclusion/exclusion, and questions about identity/difference. In other words, borders are not given but (re)produced through modes of affirmation and contestation; they are not natural, neutral nor static but historically contingent, politically charged and dynamic phenomena (Vaughan-Williams 2009, 1). For instance, Luiza Bialasiewicz (2012) examines the novel ways in which the European Union maintains its borders: something that stretches well beyond its external borders in the form of "outsourcing" migration controls to third states. Such fluidity of border management and the resulting reconfiguration of the EU sovereign space have grave implications for how sovereignty, territory and borders should be seen today. To put it more generally, the sovereign state and the modern state system do not exist $a$ priori, but are only made possible through repeated practices by statespersons, diplomats, and intellectuals all performing according to shared Westphalian "rules of the game" as "background knowledge" (Biersteker and Weber 1996).

Based on the understanding of practice outlined above, one can examine how the political practices of securing borders and claiming sovereign territories will, in turn, constitute China's identity and consequently its interests. Here, the works by William Callahan and Hiroyuki Tosa are useful. First, Callahan (2009; 2010) takes maps and cartography as political practices that produce a nation's geobody connecting space and people in a biopolitical manner. ${ }^{10} \mathrm{He}$ draws on what Thongchai Winichakul $(1994,17)$ calls the "national geobody," which is "not merely space or territory. It is a component of the life of a nation. It is a source of pride, loyalty, love, passion, bias, hatred, reason, unreason." Callahan highlights how maps are themselves manifestations of the biopolitics of national identity practice (Anderson 2006). An example of this may be found in how the safety of the fishing communities in the South China Sea is constantly invoked and used as a justification for increased security (Roszko 2015). The historical irony here is that while many of these communities were not strictly confined to any particular sovereign territory in pre-colonial Asia, not only are they now firmly part of a state but they are also mobilized as the very "stuff" of the "body politic" that needs to be defended at all costs. This is made further visible by the recent land reclamation projects, with a "population" firmly located on unambiguous "land" that needs to be protected. More than merely a scientific representation of a sovereign territory, therefore, maps have been part of a wider process of state building following the so-called "Western impact" in the region. Seen in this way, maps are deployed in the dynamics of cultural governance and resistance in China and Asia, where states seek to match territorial and cultural boundaries not only through military coercion but also through the management of identity practices (Callahan 2009, 144). Echoing studies on border politics, therefore, the 
borders of China's geobody are considered as not fixed but historically contingent, constantly produced and reproduced, and regarded as constitutive of political life.

Examples of geobody politics at play are the maps of China's national humiliation, which link imperial China's unbounded cartography and modern maps of sovereign territory. First published in China in the early twentieth century and subsequently reappearing after the Tiananmen Square incident (1989) as part of the patriotic education campaign, national humiliation maps were (and still are) produced for consumption in mass education to chart how China "lost territories" to imperialist aggressors (Callahan 2009, 146). It traces how the Qing dynasty's imperial domain, carved up by Western and later Japanese aggression, is regained and transformed into the People's Republic of China's sovereign territory today. In contrast the spatial imagination in (South)East Asia was remarkably different before the colonial encounters, with overlapping, yet non-exclusionary, territorial claims, allowing the ambiguities and tensions to be suppressed in order to naturalize "national" boundaries. ${ }^{11}$ Callahan shows how this is then grafted onto the narrative of a "century of humiliation," a master narrative that starts off with the Opium War (1840-42) and plots how the Chinese Communist Party has been the vanguard in fighting off imperialist aggressors and regaining the lost honor and pride of the Chinese people, ultimately achieving recognition as a great power (Westad 2012). ${ }^{12}$ Historical memory is thus mobilized to legitimize domestic authority and its external actions.

Yet the story does not end there, since the narrative goes on to suggest that it must recover all the "lost territory" of the imperial dynasty, including the South China Sea. Here is where the politics of the so-called nine-dash line appear, since the historically contingent demarcations on the maps suddenly emerge as clearcut sovereign territorial borders. ${ }^{13}$ Such narrative has spurred intense discussion between China and its neighbors, with countries such as Vietnam coming out with its own maps as historical evidence of its territorial claims.

Tosa $(2014 ; 2012)$ develops Callahan's arguments by drawing on insights from Critical Security Studies and Critical Border Studies. For Tosa, geobody is seen as a collective identity created through political practice (cartography) and strengthened by the performativity of borders. The performativity of borders means that borders are not just a demarcation line that separates existing sovereign territories, but a set of practices that constantly reinforce the inside/ outside distinction by chasing away the Others. To borrow a phrase from Noel Parker and Nick Vaughan-Williams (2009), borders are like "lines in the sand" in order for a border to be evident and recognized, it needs to be drawn over and over again like drawing a line in the sand. Thus, geobody is only made possible by repeated practices of border management and repetitive learning, for instance in the form of the national history of humiliation examined by Callahan (Tosa 2014, 13-15).

Rather than seeing the territorial disputes as a result of the shifting (material) 
balance of power and unambiguous identities and interests, as in the geopolitical approach, therefore, intensified territorial disputes and its associated practices such as cartography, border management, and media representations (like weather forecasts that Chinese broadcasters now offer) should be seen instead as feeding into the identity formation of the Chinese state, strengthened by geobody politics, which in turn increases the possibility of conflict. It should also be noted that the dynamics of geobody politics is not unique to China but are exhibited throughout the region. The maritime disputes in Northeast Asia between Japan and China (Senkaku/Diaoyu), Korea and Japan (Dokdo/Takeshima) and Korea and China (Ieodo/Suyan Rock/Socotra Rock) are all igniting the buildup of geobody politics, intertwined with the politics of memory and emotions. ${ }^{14}$

\section{Solitaristic Identity and the Risk of War}

As outlined above, the limits of geopolitical perspectives include the assumption that states' identities and interests are given. Accordingly, one would proceed to examine how these assumptions inform state actions. Yet it is precisely because of these assumptions that such analyses need to speculate where China's "true" identity and intentions lie. One needs to turn the traditional equation on its head: to see how political practices constitute the identity and, consequently, interests. Developing this line of argument, the following section explores the risks involved in a further escalation of tensions in the South China Sea and beyond.

A useful starting point for such an exercise is David Campbell's (1992) Writing Security: United States Foreign Policy and the Politics of Identity. For Campbell, identity is never fixed but constituted by difference: "The constitution of identity is achieved through the inscription of boundaries which serve to demarcate an 'inside' from an 'outside,' a 'self' from an 'other,' a 'domestic' from a 'foreign"' (Campbell 1992, 8). In other words, identity is always relational; identities of states are produced and reproduced in relation to others (such as other states). Campbell further draws on Charles Tilly's distinction between "nation-state" and "national state," whereby nation-states are "national states whose sovereign territorialization is perfectly aligned with a prior and primary form of identification, such as religion, language, or symbolic sense of self" (ibid., 11). This means that most states are actually "national states" — paradoxical entities that do not possess stable identities. Based on such understanding, Campbell examines how the interpretations of danger have worked, and continue to work, to establish the identity of the United States. In reading U.S. foreign policy texts from the Cold War, Campbell examines how danger came to be associated with communism and the Soviet Union. American identity is then defined as the polar opposite of the Soviets. Rather than seeing foreign policy as an expression of interests or values of a given state, therefore, Campbell 
shows how foreign policy constitutes state identity through the interpretation of danger posed by others. The implication of this work is that the notion of danger goes beyond military threats of other states to incorporate cultural and even civilizational elements.

Popularized by Samuel Huntington's "clash of civilization" thesis, the end of the Cold War and the "emergence of identity politics" have reinforced the need to take identity politics seriously (Huntington 1996). Whereas the Cold War years were characterized by the pursuit of geopolitical/ideological aims, the post-Cold War period has seen an increasing number of situations in which violence arises from conflicting identities. Correspondingly, it has been suggested that the forms of conflict and violence have also shifted from traditional wars between states (or "old wars") to new forms of organized violence. Mary Kaldor (2012) characterizes these "new wars" as intra-state, identity-driven, asymmetrical, and barbaric with no distinction between combatants and non-combatants. Rooted in a novel form of identity politics, these new types of wars are identity-driven and barbaric, which implies that "enemies" are now defined by membership in certain groups rather than their actual roles or actions. Violence is justified since the enemy is categorized as valueless and evil; hence, there is no need for hesitation. 9/11 and the following war on terror, it seems, has only exacerbated this tendency. ${ }^{15}$

Expanding on the relationship between identity and war, Kaldor (2013) goes on to argue that sectarian identity (ethnic, tribal or religious) should be seen more as an outcome of war rather than a cause of war. Drawing on Carl Schmitt's notion of friend-enemy distinction as the basis of politics, Kaldor points out that such binary distinction is a consequence of a particular type of collaborative practice and specific mode of communication; in other words, the intensification of conflict and the real possibility of being killed due to one's identity makes that identity important. An example is taken from the war in Bosnia: "Violence divided the Bosnian community into Serbs, Croats and Muslims. It established a dominant narrative of conflict that defined the identity of each side" (ibid., 339; Campbell 1998). Kaldor goes on to argue that "political violence is a way of constructing a collective friend-enemy distinction and thereby underpinning the power of the collectivity" (Kaldor 2013, 341). The implication of such observations is that wars (or the threat of wars) are not some "contest of will" between adversaries in a traditional Clausewitzian sense, but one-sided and/ or parallel efforts to construct what Amartya Sen calls "unidimensional" or "solitaristic" political identities as the basis of power. While Kaldor explores a world where wars are "outlawed" and new forms of violence and insecurities (e.g., from natural disasters such as floods and earthquakes to man-made crises like financial crises and terrorism) are prevalent, and hence are able to shape identities, the reality of the South China Sea forces one to think in terms of both rational calculation of interests between states and political mobilization of historical memory that fuels identity formation. 
Rejecting Huntington's view of an inevitable clash of civilizations, Sen (2006, xii) considers the limitation of a "solitarlist" approach to identity, which "sees human beings as members of exactly one group." The problem with this approach, as displayed by the clash of civilizations view of the world, is that it ignores the multiple identities that human beings have, given their diversity of affiliations, attachments and affinities:

The same person can be, without any contradiction, an American citizen, of Caribbean origin, with African ancestry, a Christian, a liberal, a women, a vegetarian, a long-distance runner, a historian, a school teacher, a novelist, a feminist, a heterosexual, a believer in gay and lesbian rights, a theater lover, an environmental activist, a tennis fan, a jazz musician, and someone who is deeply committed to the view that there are intelligent beings in outer space with whom it is extremely urgent to talk (preferably in English). (Sen 2006, xii-xiii)

Yet when such plural identities are suppressed and a singular identity imposed on us, it can breed violence, fostering sectarian or other divisions between people. Such risk of conflict can be further exacerbated, Sen (2008) adds, by economic inequality, poverty and injustice. While seeing political economy alone as the cause of global conflict is an oversimplification, Sen nonetheless argues that "some of the divisions between people linked with distinct racial or ethnic or other non-economic identities are made more tangible and serious through their association with poverty and inequality" (ibid., 15).

Two implications can be drawn from this analysis. First, identity politics and the politics of interests are inevitably intertwined, and should be analyzed as such. It has been outlined that great power rivalry and the "threat of war" is intensifying territorial border politics, and this in turn, is fueling the dynamics of geobody politics. Politics of identity is therefore not just a matter of "nationalistic sentiments" that have the possibility of distorting the otherwise rational calculation of strategic interests, but is instead deeply rooted in the body politic. In such circumstance, challenging China in the UN tribunal under the auspices of the UN Convention on the Laws of the Sea can invoke historical memories of Western imperial aggression (and its double standard use of international law), thereby hardening geobody politics. ${ }^{16}$ Of course, this does not mean that Beijing will (nor should) reject the legitimacy of the tribunal, but simply to suggest that it can be yet another ingredient in the historical narrative (self-)justifying its actions. In order to fully understand Chinese actions in the South China Sea, therefore, it is necessary to examine the geobody political dynamics operating in the background rather than simply applying a geopolitical view of a pursuit of economic interests or security maximization as its motive.

Second, in analyzing the prospects of peace and cooperation in the region, the dangers of solitaristic identities need to be taken into account. It has been 
noted that the increase in maritime border disputes and a threat of conflict (and even war) are fueling geobody politics in China and other nations in the South China Sea. Such dynamics are further complicated by the fact that China is depicted as a "civilizational state" (Shih and Yin 2013), where the logic of modern sovereign states and the logic of the imperial tributary system are fused into one identity under a solitaristic discourse of "peaceful rise" or "peaceful development." ${ }^{17}$ Obviously, while this is not to suggest that the modern Chinese state has been remade into a civilizational state on the lines of the great ancient dynasties, there is an element of suzerain logic collapsing into a Westphalian logic, as manifested in the nine-dash line. ${ }^{18}$ And within this fusion of logics, peaceful rise or peaceful development is not seen as a contradiction any more since, by definition, the dangers are brought in from the external Other. Thus although seemingly paradoxical, China's peaceful rise and its "aggressive" actions in the South China Sea sit comfortably together when seen in this light.

\section{Conclusion: Possibilities for Peace and Cooperation in the South China Sea and Beyond}

There has been a flurry of recent publications on the historical analogies of contemporary (South)East Asia and Europe in 1914 (Krause 2014; Chong and Hall 2014; Rosecrance and Miller 2014). While such analogies look farfetched, the risks of miscalculations or even conflict in the South China Sea should not be ruled out. Rather than miscalculations emerging from the geopolitical strategic game of economic and security maximization based on a pre-conceived notion of national interests, however, this article has argued that a more profound risk involves the intensifying of identity (or geobody) politics surrounding the maritime disputes in the South China Sea and how this affects the strategic outlook, particularly of China. This is so, because geobody politics strengthened by the performativity of borders means that the more territorial claims become problematized, the more the so-called nine-dash line and the historical narratives that underpin it become naturalized from Beijing's point of view; i.e., something that should be protected at all costs, even if that means resorting to force. And the consolidation of solitaristic identity in response to such threats of violence and war can be the most dangerous risk in the region, since the emergence of a friendenemy distinction can exacerbate the misunderstanding and miscalculations, resulting in the hardening of geobody politics that leads to more aggressive behavior. In fact, talk about a "risk of war" itself is fueling further political, military, discursive practices, in turn deepening identity politics in the region. In order to fully understand the reasons behind the seemingly contrasting messages being sent out Washington and Beijing, as seen in the introductory quotes, a renewed look at how identity (or geobody) politics is playing out is necessary to 
complement the geopolitical analysis. This should also lead to greater awareness of the risks involved in a further escalation of tensions (whether physical or verbal) for peace and cooperation in the region, and more generally in East Asia.

As Yoshikazu Sakamoto once noted: "Violence is, itself, one form of a negative identity, since it deprives value from the Other, and is conducted under the assumption that 'us' and 'them' can be clearly distinguished" (Sakamoto 2015, 461). In other words, violence happens when conflicting parties do not recognize each other's identities and/or value them as meaningful when deciding their diplomatic positions towards one another. In order to de-escalate the tensions in the South China Sea, and to devise a way forward, what is needed is to seek what Sakamoto calls "positive identity," or a collective identity that meaningfully connects the Self to the Other, and the Self to the Self. The first step towards such end may be to stop the wheel of geobody politics and the mobilization of historical memory, perhaps by learning from the successful experience of the German-Franco joint history textbook project (Durand and Kaempf 2014). Creatively imagining an "identification system" is needed: a collective identity that goes beyond any single nation/state towards a common Southeast Asian future.

\section{Notes}

1. Chinese President Xi Jinping's comments at the 60th anniversary of the Chinese People's Association for Friendship with Foreign Countries (CPAFFC). See Xinhua (2014).

2. U.S. Defense Secretary Ashton Carter's speech at the IISS Shangri-La Dialogue 2015. See Carter (2015).

3. The "nine-dash line" refers to China's territorial claims in the South China Sea; it encircles most of its waters, and includes the disputed Paracel and Spratly Islands, and the Scarborough Reef. China has justified its claims mostly through "historical" evidence, though other parties have rejected such arguments. For instance, see U.S. Department of State (2014).

4. Also see the "Thucydides Trap Project” website: http://belfercenter.ksg.harvard.edu/ publication/25760/thucydides_trap_project.html (accessed November 13, 2015). The term has even been picked up by the Chinese President Xi Jinping (Valencia 2014).

5. Such a view, albeit a minority, has been taken up within the Chinese academia as well. See Yan (2011).

6. Such suggestions are not new. See Kennedy (1989) and Gilpin (1981).

7. By contrast, see Yan (2014).

8. For a recent overview of this "practice turn," see Adler and Pouliot (2011), Kustermans (2016), and Bueger and Gadinger (2015). On its methodological implications, see Salter and Mutlu (2013) and Bueger (2014).

9. Peoples and Vaughan-Williams (2015) and Vaughan-Williams (2009) provide useful overviews on the development of Critical Security Studies and Critical Border Studies.

10. On the effects of cartography on the development of the modern state system, see 
Branch (2014).

11. It must be noted that the notion of the modern state equipped with sovereignty and territory was introduced only after the colonial encounter with the Europeans.

12. As Zheng Wang (2012) outlines, such selective use of historical memory (with history education as the instrument) has served the Chinese Communist Party well, particularly when it sought to replace traditional ideology of revolution and class struggle with nationalism as the ideological underpinnings of its legitimacy in the post-1989 era. Recent works on the "politics of humiliation" can provide useful insights to uncover the dynamics behind such narratives (Saurette 2006; Moisi 2009).

13. A similar race to use old maps and documents as historical evidence of the territorial claims can be found in North East Asia as well. For instance, compare the justifications put forward by the Korean government (http://dokdo.mofa.go.kr/eng/dokdo/reason.jsp) and the Japanese government (http://www.mofa.go.jp/region/asia-paci/takeshima/position. html) over Dokdo/Takeshima (accessed April 7, 2016).

14. On the politics of emotions, see Bleiker and Hutchison (2014).

15. This is not just a tendency of sectarian violence in the Middle East or Africa, but is found in the conduct of the "civilized," as the Guantánamo Bay and Abu Ghraib cases have shown. See among others, Danchev (2006) and Tagma (2009).

16. International law functioned as a mechanism distinguishing the "civilized nations" and the "barbarians" (and therefore not worthy of having an independent state) during colonial times. See among others, Kayaoglu (2010), Simpson (2004), and Anghie (2004).

17. The analysis of geobody politics can be combined with role theory, comparing the different "roles" that countries take or make. For instance, see Shih (2012). The author would like to thank the anonymous reviewer for pointing this out.

18. While the nine-dash line was not the most serious problem during imperial times, when the boundaries of civilizations were not so rigid and had considerable overlaps, it is problematic to simply convert that to sovereign territorial boundaries. Also, the rise of the so-called "Chinese School" can be seen as a parallel development within the academia. For instance, see Wang and Buzan (2014).

\section{References}

Adler, Emanuel, and Vincent Pouliot, eds. 2011. International Practices. Cambridge: Cambridge University Press.

Allison, Graham. 2012. “Thucydides's Trap Has Been Sprung in the Pacific." Financial Times, August 21.

Allison, Graham. 2015. "The Thucydides Trap: Are the U.S. and China Headed for War?" The Atlantic, September 24.

Anderson, Benedict. 2006. Imagined Communities: Reflections on the Origin and Spread of Nationalism. Revised ed. London: Verso.

Anghie, Antony. 2004. Imperialism, Sovereignty and the Making of International Law. Cambridge: Cambridge University Press.

Bialasiewicz, Luiza. 2012. "Off-Shoring and Out-Sourcing the Borders of EUrope: Libya and EU Border Work in the Mediterranean." Geopolitics 17 (4): 843-866. 
Biersteker, Thomas J., and Cynthia Weber, eds. 1996. State Sovereignty as Social Construct. Cambridge: Cambridge University Press.

Blackwill, Robert D., and Ashley J. Tellis. 2015. Revising U.S. Grand Strategy Toward China. New York: Council on Foreign Relations.

Bleiker, Roland, and Emma Hutchison. 2014. "Introduction: Emotions and World Politics." International Theory 6 (3): 490-491.

Branch, Jordan. 2014. The Cartographic State: Maps, Territory, and the Origins of Sovereignty. Cambridge: Cambridge University Press.

Bueger, Christian. 2014. "Pathways to Practice: Praxiography and International Politics." European Political Science Review 6 (3): 383-406.

Bueger, Christian, and Frank Gadinger. 2015. "The Play of International Practice." International Studies Quarterly 59 (3): 449-460.

Callahan, William A. 2009. "The Cartography of National Humiliation and the Emergence of China's Geobody.” Public Culture 21 (1): 141-173.

Callahan, William A. 2010. China: The Pessoptimist Nation. Oxford: Oxford University Press.

Campbell, David. 1992. Writing Security: United States Foreign Policy and the Politics of Identity. Manchester: Manchester University Press.

Campbell, David. 1998. National Deconstruction: Violence, Identity, and Justice in Bosnia. Minneapolis: University of Minnesota Press.

Carter, Ashton. 2015. The United States and Challenges of Asia-Pacific Security. IISS Shangri-La Dialogue 2015, First Plenary Session. Singapore: International Institute for Strategic Studies.

Chen, Dingding, Xiaoyu Pu, and Alastair Iain Johnston. 2013. "Debating China's Assertiveness." International Security 38 (3): 176-183.

Chong, Ja Ian, and Todd H. Hall. 2014. "The Lessons of 1914 for East Asia Today: Missing the Trees for the Forest." International Security 39 (1): 7-43.

Christensen, Thomas J. 2015. "Obama and Asia: Confronting the China Challenge." Foreign Affairs 94 (5): 28-36.

Danchev, Alex. 2006. “'Like a Dog!': Humiliation and Shame in the War on Terror." Alternatives: Global, Local, Political 31 (3): 259-283.

Durand, Jean-louis, and Sebastian Kaempf. 2014. "Reimagining Communities: Opening Up History to the Memory of Others." Millennium 42 (2): 331-353.

Gilpin, Robert. 1981. War and Change in World Politics. Cambridge: Cambridge University Press.

Hameiri, Shahar, and Lee Jones. 2016. "Rising Powers and State Transformation: The Case of China." European Journal of International Relations 22 (1): 72-98.

Huntington, Samuel P. 1996. The Clash of Civilizations and the Remaking of World Order. New York: Simon \& Schuster.

International Crisis Group. 2012. Stirring up the South China Sea I. Beijing and Brussels: International Crisis Group.

Johnston, Alastair Iain. 2013. "How New and Assertive Is China's New Assertiveness?" International Security 37 (4): 7-48.

Kaldor, Mary. 2012. New \& Old Wars: Organized Violence in a Global Era. 3rd ed. Cambridge: Polity.

Kaldor, Mary. 2013. “Identity and War." Global Policy 4 (4): 336-346. 
Kaplan, Robert D. 2014. Asia's Cauldron: The South China Sea and the End of a Stable Pacific. New York: Random House.

Kayaoglu, Turan. 2010. Legal Imperialism: Sovereignty and Extraterritoriality in Japan, the Ottoman Empire, and China. Cambridge: Cambridge University Press.

Kennedy, Paul. 1989. The Rise and Fall of the Great Powers: Economic Change and Military Conflict From 1500 to 2000. London: Fontana Press.

Kirshner, Jonathan. 2012. "The Tragedy of Offensive Realism: Classical Realism and the Rise of China." European Journal of International Relations 18 (1): 53-75.

Krause, Joachim. 2014. "Assessing the Danger of War: Parallels and Differences between Europe in 1914 and East Asia in 2014." International Affairs 90 (6): 1421-1451.

Kustermans, Jorg. 2016. "Parsing the Practice Turn: Practice, Practical Knowledge, Practices." Millennium 44 (2): 175-196.

Liff, Adam P., and G. John Ikenberry. 2014. "Racing toward Tragedy?: China's Rise, Military Competition in the Asia Pacific, and the Security Dilemma." International Security 39 (2): 52-91.

Majid, Munir. 2014. "Southeast Asian View of China's 'Not So Neighbourly' Rise." International Politics 51 (3): 398-403.

Mead, Walter Russell. 2014. “The Return of Geopolitics." Foreign Affairs 93 (3): 69-79.

Mearsheimer, John J. 2014. “Can China Rise Peacefully?” In The Tragedy of Great Power Politics, Updated, 360-411. New York: W. W. Norton.

Moisi, Dominique. 2009. The Geopolitics of Emotion: How Cultures of Fear, Humiliation and Hope Are Reshaping the World. London: Bodley Head.

Nye, Joseph S. 2011. The Future of Power. New York: Public Affairs.

Parker, Noel, and Nick Vaughan-Williams. 2009. "Lines in the Sand? Towards an Agenda for Critical Border Studies." Geopolitics 14 (3): 582-587.

Peoples, Columba, and Nick Vaughan-Williams. 2015. Critical Security Studies: An Introduction. 2nd ed. Abingdon: Routledge.

Pouliot, Vincent, and Jérémie Cornut. 2015. "Practice Theory and the Study of Diplomacy: A Research Agenda." Cooperation and Conflict 50 (3): 297-315.

Qin, Yaqing. 2014. "Continuity through Change: Background Knowledge and China's International Strategy." The Chinese Journal of International Politics 7 (3): 285-314.

Rosecrance, Richard N., and Steven E. Miller, eds. 2014. The Roots of World War I and the Risk of U.S.-China Conflict. Cambridge, MA: The MIT Press.

Roszko, Edyta. 2015. "Maritime Territorialisation as Performance of Sovereignty and Nationhood in the South China Sea." Nations and Nationalism 21 (2): 230-249.

Sakamoto, Yoshikazu. 2015. “Toward Global Identity.” In Kenryoku Seiji Wo Koeru Michi [The Road Beyond Power Politics], edited by Yoshikazu Sakamoto, 446-483. Tokyo: Iwanami Shoten.

Salter, Mark B., and Can E. Mutlu, eds. 2013. Research Methods in Critical Security Studies: An Introduction. Abingdon: Routledge.

Saurette, Paul. 2006. "You Dissin Me? Humiliation and Post 9/11 Global Politics." Review of International Studies 32 (3): 495-522.

Sen, Amartya. 2006. Identity and Violence: The Illusion of Destiny. New York: W. W. Norton.

Sen, Amartya. 2008. "Violence, Identity and Poverty." Journal of Peace Research 45 (1): 5-15.

Shih, Chih Yu. 2012. "Assigning Role Characteristics to China: The Role State Versus The 
Ego State." Foreign Policy Analysis 8 (1): 71-91.

Shih, Chih-Yu, and Jiwu Yin. 2013. "Between Core National Interest and a Harmonious World: Reconciling Self-Role Conceptions in Chinese Foreign Policy." Chinese Journal of International Politics 6 (1): 59-84.

Simpson, Gerry. 2004. Great Powers and Outlaw States: Unequal Sovereigns in the International Legal Order. Cambridge: Cambridge University Press.

Tagma, Halit Mustafa. 2009. "Homo Sacer vs. Homo Soccer Mom: Reading Agamben and Foucault in the War on Terror." Alternatives: Global, Local, Political 34 (4): 407-435.

Tharoor, Ishaan. 2014. "Could This Map of China Start a War?” Washington Post, June 27.

Tosa, Hiroyuki. 2012. "Chronotopos No Seijiteki Henyo: 4000 Nen Bunmeikokka to 100 Nen Kokuchi Chizu [Political Transformation of the Chronotope: Civilizational State of 4000 Years and National Humiliation Maps of 100 Years].” Gendai Shiso 40 (17): 59-71.

Tosa, Hiroyuki. 2014. "Overcoming the Politics of a Geobody: Exploring the Possibilities of CSS in an Asian Context." Peace Studies 43: 1-24.

Tri, Ngo Minh, and Koh Swee Lean Collin. 2014. "Lessons from the Battle of the Paracel Islands." The Diplomat, January 23.

U.S. Department of State. 2014. Limits in the Seas No. 143, China: Maritime Claims in the South China Sea. Washington, D.C.: Department of State.

Valencia, Mark. 2014. "China Needs Patience to Achieve a Peaceful Rise." South China Morning Post, February 7.

Vaughan-Williams, Nick. 2009. Border Politics: The Limits of Sovereign Power. Edinburgh: Edinburgh University Press.

Wang, Jianli, and Barry Buzan. 2014. "The English and Chinese Schools of International Relations: Comparisons and Lessons." The Chinese Journal of International Politics 7 (1): $1-46$.

Wang, Zheng. 2012. Never Forget National Humiliation: Historical Memory in Chinese Politics and Foreign Relations. New York: Columbia University Press.

Westad, Odd Arne. 2012. Restless Empire: China and the World Since 1750. New York: Basic Books.

Winichakul, Thongchai. 1994. Siam Mapped: A History of the GeoBody of a Nation. Honolulu: University of Hawaii Press.

Xinhua. 2014. “Xi: There Is No Gene for Invasion in Our Blood.” May 16.

Yahuda, Michael. 2013. "China's New Assertiveness in the South China Sea." Journal of Contemporary China 22 (81): 446-459.

Yan, Xuetong. 2011. "How China Can Defeat America." New York Times, November 20.

Yan, Xuetong. 2014. "From Keeping a Low Profile to Striving for Achievement." The Chinese Journal of International Politics 7 (2): 153-184.

Zeng, Jinghan, Yuefan Xiao, and Shaun Breslin. 2015. "Securing China's Core Interests: The State of the Debate in China." International Affairs 91 (2): 245-266.

Zhang, Feng. 2012. "Rethinking China’s Grand Strategy: Beijing's Evolving National Interests and Strategic Ideas in the Reform Era." International Politics 49 (3): 318-345. 
Hiroaki Ataka is Associate Professor at Ritsumeikan University since April 2011. He studied critical international relations theory and international political economy, and received his Ph.D. in 2010 from the University of Warwick. He is a member of Political Science Association, British International Studies Association, and the International Studies Association. He has published several articles and book chapters on Critical IR/IPE theories. His latest publication (with Norihisa Yamashita and Atushi Shibasaki) is Westphalia Shikan wo Datsukouchiku Suru [Deconstructing the Westphalian Narrative] (Nakanishiya 2016). E-mail:ataka@fc.ritsumei.ac.jp

Submitted: January 2, 2016; Revised: March 16, 2016; Accepted: April 8, 2016 
